\title{
Formulating Extension Model to Encourage Staple Food Diversification: A Solution to Food Crisis Potential
}

\author{
Ujang Maman ${ }^{1, *}$, Murodi $^{2}$, Nindyantoro ${ }^{3}$, Endin Mujahidin ${ }^{4}$, Dundin Zaenuddin ${ }^{5}$, Muhyani $^{6}$, Muksin $^{7}$ \\ ${ }^{1}$ Agribusiness Post-Graduate Program, Faculty of Science and Technology, Universitas Islam Negeri, Syarif Hidayatullah Jakarta, \\ Indonesia \\ ${ }^{2}$ Muslim Community Development Program, Faculty of Da’wah and Communication, Universitas Islam Negeri, Syarif Hidayatullah \\ Jakarta, Indonesia \\ ${ }^{3}$ Resource and Environment Department, Economic and Management Faculty, IPB University, Bogor, Indonesia \\ ${ }^{4}$ Post-Graduate Program, University of Ibnu Khaldun (UIKA), Bogor, Indonesia \\ ${ }^{5}$ Research Centre for Society and Culture, The Indonesian Institute for Science (LIPI), Jakarta, Indonesia \\ ${ }^{6}$ Islamic Education Program, Faculty of Islamic Religion, Ibn Khaldun University, Bogor, Indonesia \\ ${ }^{7}$ State Polytechnic of Jember, East Java, Indonesia
}

Received May 17, 2021; Revised July 26, 2021; Accepted August 22, 2021

\section{Cite This Paper in the following Citation Styles}

(a): [1] Ujang Maman, Murodi, Nindyantoro, Endin Mujahidin, Dundin Zaenuddin, Muhyani, Muksin , "Formulating Extension Model to Encourage Staple Food Diversification: A Solution to Food Crisis Potential," Universal Journal of Agricultural Research, Vol. 9, No. 4, pp. 138 - 148, 2021. DOI: 10.13189/ujar.2021.090405.

(b): Ujang Maman, Murodi, Nindyantoro, Endin Mujahidin, Dundin Zaenuddin, Muhyani, Muksin (2021). Formulating Extension Model to Encourage Staple Food Diversification: A Solution to Food Crisis Potential. Universal Journal of Agricultural Research, 9(4), 138 - 148. DOI: 10.13189/ujar.2021.090405.

Copyright@2021 by authors, all rights reserved. Authors agree that this article remains permanently open access under the terms of the Creative Commons Attribution License 4.0 International License

\begin{abstract}
Indonesia has been facing a high shrinkage of productive paddy land size from 16704272 ha in 1983 to 8685888 ha in 2013 which decreases to 7.46 million ha in 2019. The reduction of land size within the high growth of population who is strongly dependent on paddy rice staple food could probably bring this country food crisis. The reducing habit of paddy rice eating is valuable to solve the probable problem of rice scarcity, although it is not easy, and needs high persuasion. But unfortunately, current extension tends to only convey information and innovation, either linearly or in a dialogue, lacking a touch for behavior change. Therefore, this research aims to formulate the proper extension model to reduce the acute dependence on paddy rice. By the existence of custom community as cassava rice eater in West Java, Indonesia, the research aims to explore social interaction (SI) between the consumers of cassava rice and people living around them, the impact of SI on the food innovativeness (FI) and tendency of eating pattern change (EPC) of cassava rice eater's surrounding community, and finally the research aims to formulate extension model, which is the main purpose of this study. 182 samples who live around the custom community, are determined by Slovin formula with $5 \%$ error probability. The respondent is
\end{abstract}

taken by stratified random sampling. This survey based on path analysis proves the significant direct effect of SI toward FI. Furthermore, the indirect effect of SI on the tendency of EPC through FI is less significant. Therefore, the extension model to develop EPC should create non-rice eater community as an extension agent; and they should be encouraged to enhance SI with surrounding community. This model of extension could be a problem solution for probable food scarcity; and it of course contributes to the existed linier as well as interaction model of extension. However, making non-rice eater community is not easy but probable to implement.

Keywords Social Interaction, Food Innovativeness, Eating Pattern Change, Extension Model

\section{Introduction}

The staple food scarcity or even the staple food crisis could probably threaten many countries in the world, including Indonesia. The Economist Group has annually published the food security index based on three main 
indicators, which includes food availability, affordability, and food safety \& quality. Based on these three barometers, The Economist Group [6] has indexed 113 selected countries. The higher the index score achieved by a country, namely closer to 100 , the more perfect the country's food safety level; and likewise, the lower the index obtained by a country, namely closer to 1.00 , the country is considered as food insecure. In 2018, the highest score index was 85.9 and the lowest was 23.9. According to the Economist Group's report [6], there are 35 countries that have gotten the variation of index score between 71.3 and 85.9 that could be categorized into higher and the highest level of food secure state; 41 countries that could be grouped into the middle class of food secure states; and unfortunately, there are 37 countries that could probably got the status of food insecure and the most insecure states of food.

The food diversification, which means staple food variation, and the reduction of the acute dependence on paddy rice, will broaden the food access; and of course, it would be the proper breakthrough for the less food secure countries. The Cote d'Ivoire's experience in the military conflict period between Northern and Southern region and the interruption of food supply from Savane, a food surplus territory to the Southern food-minus region should be considered. Faul et al. [7] in his study described the successful of Cote d'Ivoire to mitigate the food crisis risk and to achieve food self-sufficiency by food diversification program.

Quoting FAO, Maman et al. [16] emphasized, food diversification benefited for food security, available nutrition; source of safe income, available job opportunity, high valuable products; farming system sustainability, and environment resilience. Similarly, the World Food Summit outlined that the food diversification contributes strongly to the food security, which consisted of: (i) physical availability of food; (ii) economic and physical access to food; (iii) food utilization; and (iv) stability of other three dimensions over times [16]. According to Kuzmin [13] by referring to Kostusenko food security is a condition when all people always have a physical and economic access to safe and nutritious food in sufficient quantities to meet their needs and preferences in food, required for an active and healthy life. Thus, the staple food diversification is very essential to enlarge the food access and food security.

The food diversification for the purpose of food security especially for Indonesia who is categorized by the WFP [28] as the lower middle-income country is very essential due to two main reasons. First, the massive productive rice field conversion is most likely uncontrolled. More than three decades of land conversion in Indonesia since 1983 up to the present time could probably bring the country to get an experience of staple food scarcity, or even suffering from food crisis. The 1983-agricultural census (AC) clearly indicated that
Indonesia owned 16704272 ha of productive rice field, irrigated by technical as well as non-technical irrigation. The rice field size has decreased to 15424004 ha in the 1993 AC, and it was counted 14139895 ha in 2003 AC. The 2013 AC proved the paddy filed areas were merely 8 685888 ha, in which Indonesia has lost almost half of the paddy fields in 1983 AC [17]. The reduction of paddy field continues. In the late 2018 the Ministry of Agrarian Affairs and Space Planning has issued the decision No. 399/Kep-23.3/X/ 2018 that the productive paddy land areas were merely 7.105.145 ha, although this Ministry has made correction to the agricultural land area; paddy field in Indonesia covers 7,46 million hectares in 2019 [4].

Secondly, the paddy land decrease has oppositely occurred within the fast population growth. The Indonesian population in 2010, according to BPS [24], was 238518.8 million; and this formal and legitimate institution in 2013 has also projected that Indonesian population will be 255 461.7 million in 2015 and 271066.4 million in 2020. This population, according to what BPS has outlined [24], will jump to 284829.0 million in 2025; 296405.1 million in 2030 and finally will become 305652.4 million in 2035. Based on birth rate, death, and life expectancy, BAPPENAS, BPS, and UNFPA [1] has also outlined the same prediction, which states that the Indonesian population will be 284829 million in 2025, and finally come to 305652.4 million in 2035. This prediction appears to have relatively high accuracy. BPS [5] has reported based on 2020-Population Census that Indonesian population in 2020 is 270.20 million. The forecasting inaccuracy is merely one million people, where the reality of Indonesian population in 2020 is one million lower than estimated.

This population growth will of course be a burden for rice supply, due to their acute dependent on paddy rice. The rice consumption rate of Indonesian people is the highest in the world, average of $139 \mathrm{~kg} / \mathrm{capita} / \mathrm{year}$, compared to Philippines who consume merely $131 \mathrm{~kg}$ of rice per year [11], although according to MoA [18], the Indonesian rice consumption rate has been reducing to 90.63 $\mathrm{kg} / \mathrm{capita} /$ year. However, this amount is still higher compared to the world rice consumption average, in which it is only $60 \mathrm{~kg} / \mathrm{capita} /$ year [11]. Due to high population growth and paddy field decreasing, FAO, IFAD, and WFP since 2014 [29] has critically reminded, it would disturb Indonesian food availability and food self-sufficiency.

The "staple food diversification" based on the above-mentioned condition is completely the "key word" to solve the problem of food crisis potential. For Indonesia, fortunately, the food diversification extension is possible based on daily eating habit, especially for rural community. Beside paddy rice, MoA [19] reported the Indonesian people consumed $1.6 \mathrm{~kg} / \mathrm{capita} /$ year of maize in 2016. In addition, the Indonesian people also have a habit to consume the cassava [20]. Regarding the land 
availability to cultivate cassava and maize, The Agricultural Statistics [21] has presented the availability of 11730930 ha dry land in which it is more than the rice field which amounted to 7,46 million ha in 2018 and 5.222.066 ha of shifting cultivation and 12.016.778 ha of unused land.

However, cassava, corn, and other food outside paddy rice is merely a supplement. They are not the staple food. People still feel hungry if they do not eat paddy rice yet. Thus, the food diversification for Indonesia should have to change the manner of eating as well as to increase the productivity of the other staple food (cassava, maize, and so on). To change this manner of course needs high persuasion. But unfortunately, the extension model is merely developed to deliver information, innovation, and furtherly explore the innovation from the grass root and it is sent back to the people. Therefore, this research based on this reason aims to formulate the high persuasion model of extension toward staple food diversification by changing the eating pattern and decreasing the acute dependence upon paddy rice staple food; and the model is hoped to be easily replicated in other countries that have mostly the same experience and circumstance with Indonesia.

The model of extension should of course be based on the empirical finding or built based on a certain case. With cassava eaters in custom community who prevent from eating the paddy rice in Cirendeu, West Java, Indonesia could be placed as the case to develop the model of extension to encourage the food diversification. The question is the extent to which the social interaction occurs between the custom people and the surrounding community; or between the surrounding people with the custom community as the cassava rice eaters. The next question is in what extent the social interaction between the two neighboring communities influence on the tendency of cassava eating and decreasing the dependence upon paddy rice. The answer to this question can be the basis for the development of an extension model for the purpose of food diversification. Therefore, the research focuses on the people that are neighbor to the custom community as cassava eaters in the above-mentioned location.

\section{Framework Analysis and Reasoning}

Eating habit and pattern are part of personality trait and consciousness that has been ingrained, and needs high persuasion to change [26]. The longstanding social interaction could possibly change the certain psychological behavior. Gantner and Kerschbamer [8] outlined, social interaction is a strength that would decide the people behavior. Referring to some theories, two researchers outlined that people's preferences and choices including drinking and smoking behavior is strongly influenced by social interaction. Referring to Gueguen el.al., Maman et al. [16] pointed out that human being tends to create affiliation and rapport when they interact each other. This assumption gets stronger by the research experience in urban slum dwellers in five administrative regions of Jakarta, Indonesia. The regression analysis in each region indicated that social interaction has a significant effect on staple food diversification in two of five regions of Jakarta [16].

Referring to Cerulo [2] and Iagulli [9], the social interaction's effect on the probable change of diet will be more significant in which the two researchers identified the impact of social interaction on certain behavior and human emotion. However, the influence of social interaction on the probable change of diet pattern should be broadly and empirically identified; and hypothetically the social interaction would have more significant indirect effect on the eating pattern change through food innovativeness.

The "in-Jakarta research" pointed out, the influence of social interaction on the tendency of diet pattern alteration was merely be found in two administrative regions, and statistically it took only the place of "significant level," while the impact of food innovativeness on the tendency eating habit change was not merely at the level of "strongly significant" but it was also found in three administrative regions of Jakarta [16]. The food innovativeness itself is influenced by various social factors [23].

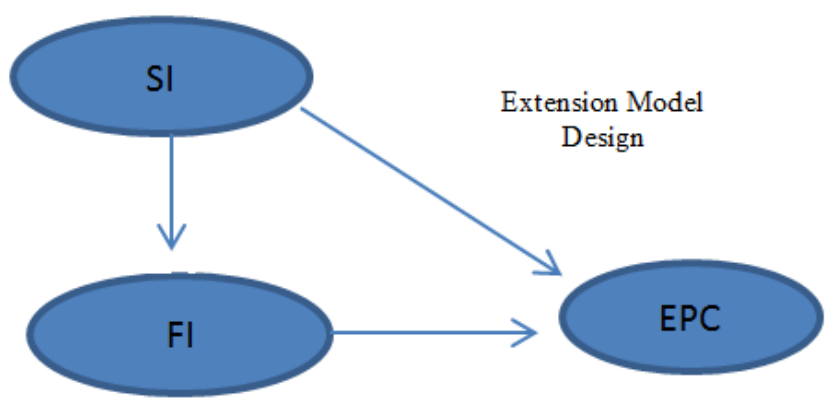

Figure 1. The Framework Analysis and Model Design

In the light of this logic, this paper tries to formulate the extension model to decrease the acute dependence on paddy rice. As is visualized in Figure 1, the indirect effect of social interaction to the diet pattern change tendency through food innovativeness will get stronger. By the existence of custom and traditional community of Cirendeu, Bandung, West Java, Indonesia as cassava rice eater community. The hypothesis model of social interaction effect on the pattern change of diet through food innovativeness will empirically be identified.

The social interaction in local context of Cirendeu, referring to Sunandar [25], includes family relationships, mutual understanding, partnership, and communication. The innovativeness is a "personality trait" induces the eagerness to change [12], a high commitment and fast 
reaction to innovation [27], and accordingly by quoting Rogers, Walley et al. [27] emphasized, innovativeness is "...the degree to which an individual or other unit of adoption is relatively early in adopting new ideas." The food innovativeness by this logic could be defined operationally as a habit and pleasure of watching, trying, and tasting a variety of certain foods and ultimately a pleasure to create a new food. This innovativeness, according to Walley at al. (27) is strongly influenced by social interaction. Finally, the eating pattern change for Indonesian context is the tendency of less dependence on paddy rice as a staple food [10]; and of course in this research the eating pattern change is frequency of cassava rice consumption and feeling satisfaction by this alternative staple food.

\section{Material and Methods}

\subsection{Research Population and Sample}

This research is a survey type which tries to conclude the parameter of population based on sample statistic. The population of this research is people who live around cassava eaters in Cirendeu, West java, Indonesia. Following the Slovin formula with 95 percent of confident level, the amount of sample is 182, and they are randomly taken from 331 family households. By this error probability level, the research outcome will get 95 percent accuracy to predict the population parameter based on sample statistic. This confidence level will be higher by the fact of relatively homogeneous population.

\subsection{Research Variable and Operational Definition}

This research presents three main variables, social interaction (SI) which is independent variable, food innovativeness (FI) which is within variable, and tendency of eating pattern change (EPC) which is dependent variable. The social interaction consists of three sub variables, namely: family relationship, mutual understanding, partnership, and communication. The operational definitions of these three variables and four sub variables are provided in Table 1.

The below variables and sub variables are measured exclusively in Likert Scale with the range based on the real condition of the research subject.

Table 1. Research Variable and Operational Definition

\begin{tabular}{|c|c|c|}
\hline Variable & Sub Variable & Operational Definition \\
\hline \multirow[t]{4}{*}{$\begin{array}{l}\text { Social } \\
\text { Interaction }\end{array}$} & Family Relationship & $\begin{array}{l}\text { The feeling of good neighbour, comfortable family relationship by } \\
\text { marriage, children adoption, and ancestral similarity with the custom } \\
\text { community }\end{array}$ \\
\hline & Mutual Understanding & $\begin{array}{l}\text { The feeling of respect and mutual understanding to the mentioned } \\
\text { indigenous community }\end{array}$ \\
\hline & Partnership & Feeling happy to work together, to help, and to reciprocate the kindness. \\
\hline & Communication & $\begin{array}{l}\text { Frequency of sending and receiving the message, warm meeting and } \\
\text { dialogue }\end{array}$ \\
\hline Food Innovativeness & - & Enjoy the habit of processing, making, and tasting cassava-based foods \\
\hline $\begin{array}{l}\text { Eating Pattern } \\
\text { Change }\end{array}$ & - & $\begin{array}{l}\text { Frequency of cassava consumption, satisfaction feeling, and a tendency } \\
\text { of more cassava consumption without rice. }\end{array}$ \\
\hline
\end{tabular}




\subsection{Validity and Reliability of Research Instrument}

The data collection was conducted in June-August 2018 by direct observation and interview by close question before the case of covid-19 pandemic in Indonesia. The instrument of this research is completely used to collect the data after measurement of validity and reliability level based on Cronbach's alpha test [22], in which the instruments get score more than 0.6, which indicates the questionnaire has met the research requirement.

\subsection{Hypotheses and Data Analysis}

This research ranks three main variables into high, moderate, and low by adopting the following formula:

The Highest Score of Likert Scale

Range: - The lowest Score of Likert Scale The Used Likert Scale

In the next stage, based on the research purpose to formulate the extension model, the data analysis is aided by path analysis and structural equation modelling (SEM) to examine the hypothesis that: (a) the social interaction and food innovativeness affect directly and significantly to the tendency of diet pattern alteration; (b) the social interaction affects indirectly and strongly significant through food innovativeness to the tendency of eating pattern change.

\section{Result and Discussion}

\subsection{Respondent Distribution by Age, Job, and Non-Paddy Rice Consumption}

The respondent distribution by three characteristics mentioned above is very important because of the strong relationship with the potential of food diversification. The job and age are significant factors represent the ability to make a proper decision, and to find the way out of the critical issue in their life. Commonly, the young age has the strong inclination innovatively to perform the more valuable idea and practice. The different job will lead someone to the diversity of friendliness, modernity, relationship, and capacity to select various messages.

About job, the respondents have various types of work. The research, pleasantly, finds $41.20 \%$ of the respondents are housewife and $7.6 \%$ of them are entrepreneurs. The housewife position in Indonesian culture has a close relationship with the food variety because culturally, their task is to provide food for their family members. Thus, their position will lead to taste variety of additional foods, in which it is a valuable habit for food innovativeness and finally will come to food diversification. In addition, the entrepreneurs generally love freedom, and enjoy trying everything, including tasting different forms of food. Therefore, the position of entrepreneurs and housewives is social capital for development of food diversification. Thus, the research has found respondents, which are high potential to extent food innovativeness.

Most respondents in this research are of productive age, namely $20-40$ years. More than $50 \%$ of the respondents are the young age. The respondents who have the old age, between 40 and 60 years, are less than $40 \%$. However, the older age above sixties is merely $7.14 \%$. By considering most of the young age, the respondents hypothetically have strong probability to lead food innovativeness, and potentially to change their habit of diet, in which they will be less dependent upon paddy rice.

The potential of change of their diet habit is strengthened by daily meals. Most respondents of this research $(81.33 \%)$ have had a habit to consume cassava as a food supplement. The respondents who have the habit to eat corn and potato are $12.08 \%$ and $6.59 \%$, respectively (Table 2), a small number compared to the cassava consumers. In the light of this evidence, it is strongly potential to change the pattern of diet to decrease the strong dependence on paddy rice as a daily main meal.

Table 2. Age, Job, and Non-Paddy Rice Consumption

\begin{tabular}{|c|c|c|c|}
\hline \multirow{4}{*}{ Characteristic } & Category & Frequency & (\%) \\
\hline \multirow{4}{*}{ Age } & 20 - 40 Year & 98 & 53.84 \\
\cline { 2 - 4 } & 40 - 60 Year & 71 & 39.02 \\
\cline { 2 - 4 } & $>60$ Years & 13 & 7.14 \\
\cline { 2 - 4 } & Total & 182 & 100.00 \\
\hline \multirow{7}{*}{ Job } & Private worker & 17 & 9.35 \\
\cline { 2 - 4 } & Casual Worker & 69 & 37.92 \\
\cline { 2 - 4 } & Housewife & 75 & 41.20 \\
\cline { 2 - 4 } & Entrepreneur & 14 & 7.69 \\
\cline { 2 - 4 } & Honorary & 7 & 3.84 \\
\cline { 2 - 4 } & employee & 182 & 100.00 \\
\hline $\begin{array}{c}\text { Non-Rice } \\
\text { Consumption }\end{array}$ & Potato & 12 & 6.59 \\
\hline \multirow{4}{*}{} & Cassava & 148 & 81.33 \\
\hline & Corn & 22 & 12.08 \\
\hline & Total & 182 & 100.00 \\
\hline
\end{tabular}

\subsection{Social Interaction of Cassava Eater Surrounding Community}

The social interaction in this research consists of four sub-variables: family relationship, understanding, partnership, and communication. The measurement result of family relationship proves most respondents (80.21\%) get a moderate level of this dimension of social interaction. The respondents who get high level of family relationship is merely $19.79 \%$, and fortunately this measurement shows the absent of low level of family relationship (Table 3). Regarding the mutual understanding between 
two neighbouring communities, it is merely $18.13 \%$ of respondents who get a high level of this sub-variable, and there are not interviewees get the low level of mutual understanding. Most respondents (81.87\%) are the same with the previous sub-variable, namely they get a moderate level of mutual understanding.

The number of respondents who are categorized into high in partnership level is more than the respondents who are categorized into the same level for family relationship and understanding, although most respondents are in the position of moderate level for partnership as well as communication. The respondents who get moderate in partnership for more detail are $66.49 \%$, and $75.28 \%$ in communication. Therefore, the partnership is more popular and mostly carried out by the two neighboring community groups. Based on the sequence, the most frequent social interaction activities are partnership, communication, family relationship, and mutual understanding (Table 3).

Table 3. Social Interaction Level and Its Distribution

\begin{tabular}{|c|c|c|c|}
\hline $\begin{array}{c}\text { Sub } \\
\text { Variable }\end{array}$ & Category & Freq & $\%$ \\
\hline \multirow{4}{*}{$\begin{array}{c}\text { Family } \\
\text { Relationship }\end{array}$} & High $(3.2-4,0)$ & 36 & 19.79 \\
\hline & Moderate (2.1-3.1) & 146 & 80.21 \\
\hline & Low (1-2) & 0 & 0 \\
\hline & Total & 182 & 100 \\
\hline \multirow{4}{*}{$\begin{array}{c}\text { Mutual } \\
\text { Understanding }\end{array}$} & High (3.2-4.2) & 33 & 18.13 \\
\hline & Moderate (2.1-3.1) & 149 & 81.87 \\
\hline & Low (1-2) & 0 & 0 \\
\hline & Total & 182 & 100 \\
\hline \multirow{4}{*}{ Partnership } & High (3.2-4.2) & 61 & 33.51 \\
\hline & Moderate (2.1-3.1) & 121 & 66.49 \\
\hline & Low (1-2) & 0 & 0 \\
\hline & Total & 182 & 100 \\
\hline \multirow{4}{*}{ Communication } & High (3.2-4.2) & 43 & 23.63 \\
\hline & Moderate (2.1-3.1) & 137 & 75.28 \\
\hline & Low (1-2) & 2 & 1.09 \\
\hline & Total & 182 & 100 \\
\hline
\end{tabular}

\subsection{Food Innovativeness}

The research fortunately proves a high tendency of food innovativeness within the respondents, but unfortunately the tendency of eating pattern change is low. This research finds that 45 respondents (24.72\%) of the 182 respondents could be categorized into high in their habit of food innovativeness. In other sides, the research merely finds 32 respondents (17.58\%) who could be grouped into high tendency of eating pattern change. However, in general, the tendency of food innovativeness and eating pattern change is relatively moderate. From 182 respondents of this research, there are 133 interviewees (73.09\%) who take position of moderate in tendency of food innovativeness. But pleasantly, the interviewees who could be categorized in low of food innovativeness are merely four respondents (2.19\%).

Table 4. The Level of Food Innovativeness and Eating Pattern Change

\begin{tabular}{|c|c|c|c|}
\hline Variable & Category & Freq & \% \\
\hline \multirow{4}{*}{$\begin{array}{c}\text { Food } \\
\text { Innova-tiveness }\end{array}$} & High (3.2-4.2) & 45 & 24.72 \\
\cline { 2 - 4 } & Moderate (2.1-3.1) & 133 & 73.09 \\
\cline { 2 - 4 } & Low (1-2) & 4 & 2.19 \\
\cline { 2 - 4 } & Total & 182 & 100 \\
\hline \multirow{3}{*}{$\begin{array}{c}\text { Eating Pattern } \\
\text { Change }\end{array}$} & High 3.2-4.2) & 32 & 17.58 \\
\cline { 2 - 4 } & Moderate (2.1-3.1) & 125 & 68.68 \\
\cline { 2 - 4 } & Low (1-2) & 25 & 13.74 \\
\cline { 2 - 4 } & Total & 182 & 100 \\
\hline
\end{tabular}

The majority of respondents who gets moderate position - although it is not in high level -- of food innovativeness indicates the high potential of interviewees to reduce the strong dependent upon paddy rice as main meal. The food diversification could potentially be developed within the people who live in surrounding area of custom community. However, the research will present furtherly the tendency of eating pattern change.

\subsection{The Tendency of Eating Pattern Change}

The high as well as the moderate tendency of food innovativeness as mentioned above arouses the question about to what extent the respondents have the tendency to decrease their dependence on paddy-rice staple food. This research objective aims to answer this inquiry. This research, pleasantly, finds $17.5 \%$ of the interviewees or 32 respondents from 182 people of the research samples have high potential to change the pattern of eating, in which the paddy-rice could gradually be replaced by the cassava-rice or cooked cassava-rice. But, unfortunately, most of the research subjects (68.68\%) get merely the moderate position, although there is also a potential to decrease the strong dependence upon paddy-rice as staple food (Table 4).

The tendency of eating pattern change is measured exclusively based on the frequency of eating of various foods created from cassava; the cooked cassava rice; and also, enjoyable feeling of food supplement as well as the staple food from cassava rice; frequency of un-hungry feeling after eating food supplement as well as main food created from cassava rice; and also, the frequency of hungry feeling after eating food supplement as well as the main food processed from cassava.

\subsection{The Social Interaction Effect on the Inclination of Diet Pattern Alteration}

This study browses the social interaction effect on the 
inclination of diet pattern change in path analysis model. This process is implemented in five main stages, includes: (1) the correlation analysis in Pearson's model; (2) the analysis of social interaction effect directly on the food innovativeness; (3) the social interaction and food innovativeness effect directly on the inclination of diet pattern change; (4) the analysis of social interaction effect indirectly on the inclination of diet pattern change through food innovativeness; and finally (5) the formulation of an appropriate model of agricultural extension toward staple food diversification based on the direct and indirect effect of social interaction on decreasing strong dependence on paddy-rice staple food.

\subsubsection{The Correlation between Social Interaction, Food Innovativeness and Eating Pattern Change}

The result of Pearson correlation analysis as a pre-condition for further analysis of path model is presented in Table 5. The Pearson correlation could be commonly categorized into: strongly low (0.00-0.1999), low (0.20-0.399), moderate (0.40-0.599), strong (0.60-0.799), and very strong (0.80-1.000) [30]. In light of this category, social interaction has a moderate correlation with food innovativeness; and low correlation with eating pattern change. The food innovativeness has also a low correlation with the eating pattern change.

Based on the result of this analysis, it could hypothetically be outlined that the social interaction is a predictor for food innovativeness, and in contrary it is not a right predictor for eating pattern change. In other sentence, the social interaction with its sub variables would have a direct effect on the food innovativeness and eating pattern change. But, fortunately, the indirect effect of social interaction on the inclination of diet pattern change will be more significant through the food innovativeness. It will strongly be clear by path model analysis.

Table 5. Correlation between Social Interactions, Food Innovativeness and Eating Pattern Change

\begin{tabular}{|c|c|c|c|c|}
\hline V-1 & V- 2 & PC & CC & P-v \\
\hline SI & FI & 0.539 & Moderate & $0.000^{* *}$ \\
\hline SI & EPC & 0.255 & Low & 0.071 \\
\hline FI & EPC & 0.257 & Low & $0.029^{*}$ \\
\hline
\end{tabular}

Note:

SI: Social Interaction

FI: Food Innovativeness

V: Variable

PC: Pearson Coefficient

CC: Correlation Category

P-v: P-value

\subsubsection{The Direct of Social Interaction Effect to the Food Innovativeness}

In line with the previous hypothetical statement, the social interaction has a significant direct effect strongly on the food innovativeness. Each sub -variable of the social interaction family relationship, understanding, partnership and communication has the same effect on the tendency of food innovativeness. The conclusion is based on the path coefficient and its $\mathrm{V}_{\text {-value }}$ as well as the comparison between $\mathrm{T}_{\text {Table }}$ and $\mathrm{T}_{\text {Count }}$, in which the $\mathrm{T}_{\text {Count }}$ is bigger than $\mathrm{T}_{\text {Table. If }}$. the $\mathrm{T}_{\text {Count }}$ is smaller than $\mathrm{T}_{\text {Table, }}$, it strongly indicates the absence of the effect of independent variable on the dependent variable. The result of effect analysis in path model is completely presented in Table 6 .

The sub-variable of communication takes the first ranking by its effect on the food innovativeness. The partnership and mutual understanding take the second and the third ranking based on each effect on the food innovativeness. In this ranking of the influence to the food innovativeness, the family relationship proves taking the lowest place (Table 6). This finding of course arouses the further question about the direct effect of social interaction with its four sub-variables to the eating pattern change. In the next stage of this path analysis, this question is answered.

Table 6. Social Interaction, Path Coefficient and Food Innovativeness

\begin{tabular}{|c|c|c|c|}
\hline \multirow{2}{*}{$\begin{array}{c}\text { Variable and Sub } \\
\text { Variables }\end{array}$} & \multicolumn{3}{|c|}{ Food Innovativeness } \\
\cline { 2 - 4 } & $\begin{array}{c}\text { Path } \\
\text { Coefficient }\end{array}$ & $\mathbf{T}_{\text {Count }}$ & $\mathbf{P}_{\text {Values }}$ \\
\hline Social Interaction & 0.539 & 8.340 & $0.000^{* *}$ \\
\hline Family Relationship & 0.140 & 3.879 & $0.000^{* *}$ \\
\hline Mutual Understanding & 0.128 & 4.051 & $0.000^{* *}$ \\
\hline Partnership & 0.187 & 5.345 & $0.000^{* *}$ \\
\hline Communication & 0.209 & 5.937 & $0.000^{* *}$ \\
\hline
\end{tabular}

Note: ** : Strongly Significant

* : Significant

\subsubsection{The Direct Effect of Social Interaction and Food Innovativeness to the Diet Pattern Alteration}

Each sub-variable of the social interaction indicates the significant influence on the tendency of eating pattern change. Therefore, this factor has high probability to support the decreasing of strong dependence upon paddy rice. The food innovativeness also proves its significant effect to the same variable (Table 7).

Table 7. The Effect of Social Interaction and Food Innovativeness to the Diet Pattern Alteration

\begin{tabular}{|c|c|c|c|}
\hline \multirow{2}{*}{$\begin{array}{c}\text { Variable/Sub } \\
\text { Variable }\end{array}$} & \multicolumn{3}{|c|}{ Eating Pattern Change } \\
\cline { 2 - 4 } & $\begin{array}{c}\text { Path } \\
\text { Coefficient }\end{array}$ & $\mathbf{T}_{\text {Count }}$ & $\mathbf{P}_{\text {Values }}$ \\
\hline Social Interaction & 0.164 & 1.773 & 0.071 \\
\hline Family Relationship & 0.066 & 2.617 & $0.009^{* *}$ \\
\hline Mutual Understanding & 0.061 & 2.484 & $0.013^{* *}$ \\
\hline Partnership & 0.089 & 3.462 & $0.001^{* *}$ \\
\hline Communication & 0.099 & 3.568 & $0.000^{* *}$ \\
\hline Food Innovativeness & 9.168 & 3.568 & $0.029^{*}$ \\
\hline
\end{tabular}

Note : ** : Strongly Significant, * : significant 
This research proves the social interaction as the whole does not influence the tendency of eating pattern change. However, fortunately, the four sub-variables of social interactions indicate the strong significant effect on eating pattern change. The food innovativeness also contributes to the tendency of decreasing strong dependence on paddy-rice. But unpleasantly, it merely indicates the existence of the effect, not completely presents the weight of its influence. The next analysis is of course necessary to browse the weight influence of each variable and sub variables on the eating pattern change.

In addition to the existence of the influence of food innovativeness to the tendency of eating pattern change, it hypothetically could be a strong indication that the social interaction will get strong indirect effect to the eating pattern change through the food innovativeness.

\subsubsection{The Indirect Effect of Social Interaction to the Diet Pattern Alteration}

The research has deeply browsed the contribution of each four sub-variables family relationship, understanding, partnership and communication to the social interaction sequentially by each weight. By the aid of structural equation modelling (SEM) analysis, communication got the first rank (7.384\%), which is followed by partnership (5.673\%), mutual understanding (4.896\%), and family relationship (4.992\%) based on each weight of contribution to the social interaction (Figure 2.). This research of course could not browse other factors except for the four mentioned sub variables because the focus of this research is merely on the four sub variables.

The effect of social interaction directly on the diet pattern alteration in light of SEM model analysis was relatively small. The weight of its effect is merely $1.773 \%$ (Figure 2). However, the weight of its effect is relatively big and significant indirectly through food innovativeness. The weight of effect of social interaction on the food innovativeness is $8.364 \%$; and the food innovativeness contributes $2.207 \%$ to the tendency of eating pattern change. The total effect of social interaction directly as well as indirectly on the eating pattern change is no more than $13 \%$. In light of this finding, social interaction is the major factor that forms the food innovativeness. However, in spite of the relatively small effect, the social interaction especially the communication and partnership is the proper way to decrease strong dependence on paddy rice.

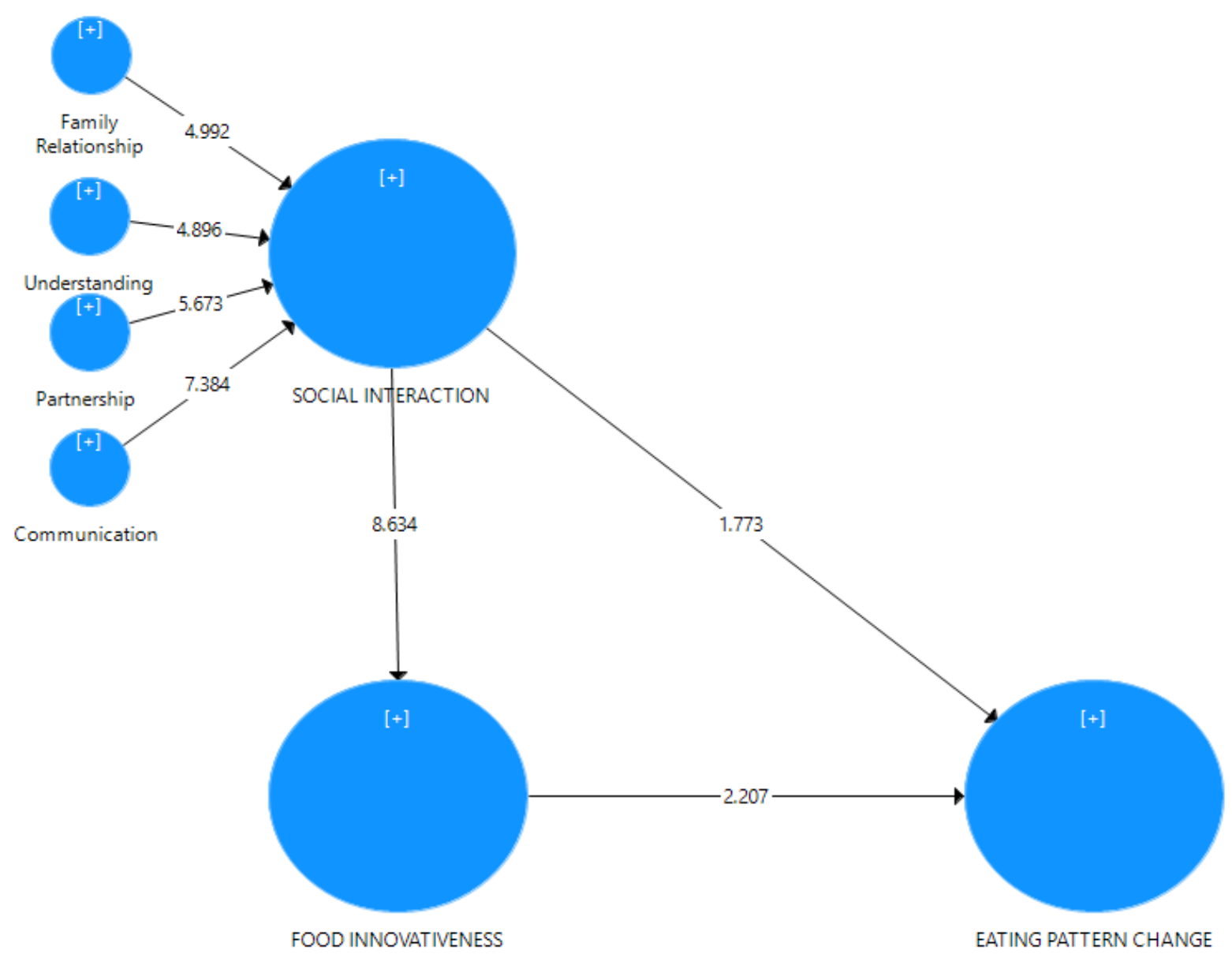

Figure 2. The Indirect Effect of Social Interaction on the Diet Pattern Alteration 


\subsection{The Elaboration of Model to Implement}

The model in agricultural extension refers to a process of delivering the message or innovative idea and practices from the source to the recipients. The model also describes the flow of information from the resources system to the user system, and presents the position, role, and involvement of extension agents in the process of delivering messages to encourage adoption of innovation [3]. The linier model, for instance, indicates the process of message delivering from the source system to the recipient in one way traffic of communication [14]. Dialogue model is contrary to the linier way, in which the process absorbs the idea, information, condition, and also let the participant come to a decision in implementing the certain way to solve the problem. The field school model popularly assumes the extension agent or a trainer as a facilitator, while the farmer as a participant existed in a parallel line with the extension agent, or even let the farmer as the expert, not merely a recipient; and this process could significantly decrease the gap of knowledge and adoption of innovation. However, the dialogue of field school model has not been completely successful to change the daily habit, which indicates the extension needs other models that present the high persuasion process [15].

The creation of the social interaction model could enhance and develop the existed model specially to reduce an acute dependence on certain staple food; and it is valuable because of the uncomplete success in the linier and dialogue model in changing behavior. This model could also be implemented in other filed, in development of integrated pest management, organic farming system, hygiene behavior development, and so on.

The social interaction model initiated in this paper place the extension agent as a community practitioner, not as a trainer, message informer, or a participant. As a community practitioner, the agent should present a high persuasion to change the attitude, habit, behavior the diet pattern and to decease high dependent on certain staple food. In light of previous Path/SEM model, the social interaction between cassava eater and surrounding community presents a high persuasion to encourage a habit and a pleasure to create and taste a variation of food made of the cassava raw material, although the model in this case has not been successful to change completely the eating pattern and decreasing the dependence upon paddy rice. In other words, the community practitioners could be a role model to develop and change certain behavior through the interaction process.

The cassava eater in this research has existed and been given, not created by the community practitioner. But, obligatory, in the "real world" the extension agent in implementing this model to change the eating pattern should creatively make social groups and they must get used to eating certain staple foods, not entirely dependent on a particular staple meal. The other social groups could be created for the certain purposes. For the part of Rural Kebeles community of Harari Region, in Ethiopia, for example, social practitioner groups could be designed to develop the hygiene life such as handwashing with soap and water before food processing, before eating food, and after visiting toilet, in which this hygiene life does not become their habit yet for part of them [31].

The created social group should have to enlarge the social interaction with surrounding communities majorly in the form of warm communication, partnership, mutual understanding and if it is possible to do a family relationship. This persuasive model in certain time and period will certainly change certain behaviour such as the manner of eating and something to eat, but it should be periodically evaluated in socio-economic condition. However, making the social groups and initiating the certain pattern of diet is not easy but possible to create.

\section{Conclusions}

The main dimension of social interaction (SI) that should be emphasized in the extension model to reduce high dependence on paddy-rice is communication and partnership. The SI between the cassava eater and surrounding communities has influenced the food innovativeness (FI) directly, especially inducing a habit and pleasure to create food variation made of cassavas. However, the SI does not have the indirect effect through FI on reducing the strong dependence on paddy-rice as daily main food.

The result of this research could be implemented by creating the innovative social groups (ISG), enhancing SI between the ISG and surrounding community to decrease the strong dependence on paddy rice, and the result should be periodically evaluated. The ISG should deliver warm communication and partnership to the surrounding community of ISG. However, the socio-economic condition could probably influence the perfect result of this research on decreasing the habit of rice eating.

Based on this conclusion, the research recommends creating innovative ISG as an initiator of food diversification and cassava eaters. The same ISG could also be formed for other innovative purposes, such as extending the hygienic life. However, it should be noted that the innovative ISG to change the eating habit is not easy because the daily meal of the member of this ISG has the same manner, in which they also depend upon the paddy rice staple food. Yes, it is not easy to change themselves before encouraging other people to change, but it is possible to implement.

\section{Acknowledgements}

The authors highly appreciate the Center for Research and Publication, State Islamic University of Syarif 
Hidayatullah Jakarta, Indonesia for funding this research in fiscal year of 2018.

\section{REFERENCES}

[1] BAPPENAS, BPS, and UNFPA, “General Description,” in Indonesian Population Projection 2015-2045, Revised Edition, BAPPENAS, BPS, and UNFPA, 2018, pp. 1-6. https://indonesia.unfpa.org/id/node/40495.

[2] Cerulo, M., "The Sociological Study of Emotions: Interactionist Analysis Lines.” Italian Sociological Review, vol. 9, no. 2, pp 183-194, 2019. DOI: http://dx.doi.org/10.1 3136/isr.v9i2.275

[3] Chand, A. and Kumar, S., "Changing Agriculture Extension Models in Pacific Island Countries,” Journal of Agricultural Extension, vol. 23, no. 4, 2019, pp. 30-38, DOI: https://dx.doi.org/10.4314/jae.v23i4.4

[4] Siregar, Efrem., "Data Luas Sawah Dikoreksi, Bertambah dari 7,1 Juta Ha,” [The Rice Field Size Data was Corrected, Increasing from 7.1 Million Ha," in CNBC Indonesia, https://www.cnbcindonesia.com/news/20191031132833-4111670/data-luas-sawah-dikoreksi-bertambah-dari-71-jutaha (Accessed May 25, 2021)

[5] Badan Pusat Statistik, "Hasil Sensus Penduduk 2020" [The Result of 2020 Population Census]. BPS, 2020, https://www.bps.go.id/pressrelease/2021/01/21/1854/hasilsensus- penduduk-2020. html. (Accessed May 25, 2021)

[6] The Economist Group. (2018). Global Food Security Index 2018: Build resilience in the face of rising food-security risks. The Economist Group.

[7] Faul, S., Shonghoy, A.S., and Dabalen, A. "Food Crop Diversification as a Risk Mitigation Strategy: Evidence from Cote d'Ivoire,” IDE Discussion Paper No. 496, JETRO, 2015: wp (without pages).

[8] Gantner, A. and Kerschbamer, R. "Social Interaction Effects: The Impact of Distributional Preferences on Risky Choices,” Journal Risk Uncertain, vol. 56, 2018, pp. 141-164,https://link.springer.com/content/pdf/10.1007/s11 166-018-9275-5.pdf

[9] Iagulli, P. "Interactionism and the Sociology of Emotions." Italian Sociological Review, vol 9, no 2, 2019, pp. 195-208, DOI: http://dx.doi.org/10.13136/isr.v9i2.276

[10] Imelda, Kusrini, N. and Hidayat, R. "Development Strategy of Local Food Diversification.” JEJAK Journal of Economics and Policy, vol. 10, no. 1, pp. 62-79, 2017, DOI: http://dx.doi.org/10.15294/jejak.v10i1.9127

[11] The Economist Group. (2018). Global Food Security Index 2018: Build resilience in the face of rising food-security risks. The Economist Group.

[12] Khan, M.M, and Khan, S. (WY). “An Analysis of Consumer Innovativeness and Cognitive Buying Behavior of Young Adult: An Empirical Study on University Student," The Journal of Commerce, vol. 5, no. 4, pp. 11-26, WY, http://joc.hcc.edu.pk/articlepdfZia\%20sb_11_26.pdf
[13] Kuzmin, E.A. "Sustainable Food Security: Floating Balance of Market," International Journal of Economics and Financial Issues, vol, 6, no. 1, pp. 37-44, 2016, https://www.econjournals.com/index.php/ijefi/article/view File/1575/pdf

[14] Maman U. and Nugraha, A.T. "Revitalization of Linier Model of Extension to Disseminate the Paddy Crop Failure Insurance.” International Journal of Applied Agricultural Research, vol. 14, no. 1, 1-14, 2019, http://www.ripublicati on.com/Volume/ijaarv14n1.htm

[15] Maman,U., Nurhandayanti, E., and Yoga, H.H., "The Effectiveness of Farmer Field School in Dissemination of Innovation: The Case of Orchid Farmer in Tangerang Banten and Onion Farmer in Berebes Central Java," The Middle East Journal of Scientific Research, vol 23, no. 12, pp. 2927-2936, 2015, DOI: 10.5829/idosi.mejsr.2015.23.1 2.22874 .

[16] Maman, U., Fahriany, Sugiarti,Y. and Jie, F., Determinant Factors toward Staple Food Diversification: Evidence from Indonesia Context, The Social Sciences, vol. 12, no. 9, pp. 1724-1730, 2017, DOI: 10.3923/sscience.2017.1724.1730

[17] Maman, U. Kusmana, and Supiandy, D., “Al-Musaqah” and Sharia Agribusiness System: An Alternative Way to Meet Staple Food Self-Sufficiency in Contemporary Indonesia,” Hunafa: Jurnal Studia Islamika, vol. 14, no. 2, pp. 189-231, 2017, DOI: http://dx.doi.org/10.24239/jsi.v14i2.448.189-2 31

[18] MoA., Buletin Konsumsi Pangan [Food Consumption Bulletin], vol. 10, no. 1, 2019, pp.20-31, http://epublikasi.setjen.pertanian.go.id/arsip-buletin/53-bul etin-konsumsi/579-buletin-konsumsi-pangan-semester-1-2 018

[19] MoA., Outloook Komoditas Tanaman Pangan Jagung [Outlook on Corn Food Commodities], The centre for Data and Agricultural Information System, 2018, pp. 16-23, http://perpustakaan.bappenas.go.id/lontar/file?file=digital/ 166967-\%5B_Konten_\%5D-Konten\%20D1884.pdf

[20] MoA., Outloook Komoditas Tanaman Pangan Singkong [Outlook on Cassava Food Commodities], The centre for Data and Agricultural Information System, 2016, pp. 16-17, http://epublikasi.setjen.pertanian.go.id/epublikasi/outlook/ 2016/Tanpang/OUTLOOK\%20UBIKAYU\%202016/files/ assets/common/downloads/OUTLOOK\%20UBIKAYU\%2 02016.pdf

[21] MoA., “Agricultural Statistics 2018,” The Centre for Data and Agricultural Information System, 2018, pp 1-3, http://epublikasi.setjen.pertanian.go.id/arsip-perstatistikan/ 160-statistik/statistik-pertanian/586-statistik-pertanian-202 0

[22] Tavakol, M. and Dennick R. (2011), "Making sense of Cronbach's alpha," International Journal of Medical Education 2, 53-55. Doi: 10.5116/ijme.4dfb.8dfd

[23] Passaro, P. and Salomone, S. "Consumer Innovativeness in Food Industry: From Literature Review Some Indications for Business Practices.” International Journal of Business Administration, Vol. 8, no. 2, pp. 10-24, 2017, DOI: http://dx. doi.org/10.5430/ijba.v8n2p10.

[24] BPS. "Hasil Perhitungan” [Calculation Result],” In Proyeksi Penduduk Indonesia 2010- 2035, BPS, 2013, pp. 
23-24,https://www.bappenas.go.id/files/5413/9148/4109/P royeksi_Penduduk_Indonesia_2010-2035.pdf

[25] Sunandar, D. (2017). “Tinjauan Pustaka.” Pengaruh Interaksi Sosial Terhadap Perilaku Konsumsi Pangan Ubi Kayu. Studi Kasus: Kampung Cireundeu, Kelurahan Lewigajah, Kecamatan Cimahi [The Effect of Social Interaction to the Food Consumption Behavior. Case Study: Cirendeu Village, District of Leuwigajah, Cimahi Regncy ], UIN Syarif Hidayatullah Jakarta, Indonesia, 2017, pp. 18-31, https://repository.uinjkt.ac.id/dspace/handle/123456 $789 / 55073$

[26] Olsen, SO, Tuu, HH, Honkanen, P \& Verplanken, B. "Conscientiousness and (un)healthy eating: the role of impulsive eating and age in the consumption of daily main meals.” Scandinavian Journal of Psychology, vol. 56, no. 4 , pp. 397-404, 2015 DOI: https://doi.org/10.1111/sjop.12220

[27] Walley, K., Goodall, S., Humphries, A., Huntington, J., White, D. and Asson, T. "Key Dimensions of Personal Innovativeness." International Journal of Business and Innovation, vol 12, no. 2, pp. 1-21, 2017, DOI: http://dx.doi.org/10.1504/IJBIR.2017.10001672
[28] World Food Program., WFP Indonesia Country Brief. WFP, 2019. https:/docs.wfp.org/api/documents/WFP-000007377 7/download/ (accessed, Mey 25, 2021)

[29] FAO, IFAD and WFP. "The State of Food Insecurity in the World: Strengthening the Enabling Environment for Food Security and Nutrition.” FAO, pp.29-31, 2014. http://www.fao.org/3/i4030e/i4030e.pdf

[30] Schober, Patrick., Christa Boer, and Lothar A. Schwarte (2018), Correlation Coefficients: Appropriate Use and Interpretation. ANESTHESIA \& ANALGESIA Vol. 18, pp. 1763-1768. DOI: 10.1213/ANE.0000000000002864

[31] Desta Dugassa Fufa, Aklilu Abhram, Awgichew Teshome, Kedir Teji, Fistum Abera, MaledaTefera, Meron Yeshitila, Melese Mengistu, Muluken Gezahegn, Tadesse Gure, Teshager Worku, Tadesse Alemayehu, Gudina Egata, "Hygienic Practice of Complementary Food Preparation and Associated Factors among Mothers with Children Aged from 6 to 24 Months in Rural Kebeles of Harari Region, Ethiopia,” Food Science and Technology 8(2), pp. 34-42, 2020; DOI: 10.13189/fst.2020.080203 